\title{
SEVERE DENTAL CALCULUS AND NON-SURGICAL PERIODONTAL TREATMENT: A CASE REPORT
}

\section{ŞİDDETLİ DİŞTAŞI VARLIĞI VE CERRAHİSİZ PERİDONTAL TEDAVİ: BİR OLGU SUNUMU ${ }^{*}$}

Arş. Gör. Dt. Gurbet Alev ÖZTAŞ*

Prof. Dr. Recep ORBAK ${ }^{* *}$

Makale Kodu/Article code: 4151

Makale Gönderilme tarihi; 09.09.2019

Kabul Tarihi: 05.12 .2019
DOI : $10.17567 /$ ataunidfd.655565

Gurbet Alev Öztaş: ORCID ID: 0000-0002-0565-6194

Recep Orbak: ORCID ID: 0000-0002-2398-9291

\section{ABSTRACT}

Poor oral hygiene, combined with adverse local and systemic factors, may lead to more severe periodontal diseases. A 17-year-old girl with tooth and gum problems was admitted to our clinic. Intraoral examination revealed that oral hygiene was inadequate and there was a severe calculus extending up to the occlusal surface (approximately $20 \mathrm{~mm} \times 12 \mathrm{~mm}$ ). Her medical anamnesis showed no significant findings, but she had oral respiration and had difficulty in communicating with her environment. Oral hygiene education was given and debridement was performed at regular intervals. Follow-up sessions, it was observed that she was satisfied with treatment, paid attention to her oral hygiene and her self-confidence increased. The patient was referred to the Orthodontics and Ear-Nose-Throat clinics to prevent recurrence of problems after satisfactory recovery.

Even with good oral hygiene training and initial periodontal treatment, severe periodontal problems can be solved and quality of life can be recovered.

Keywords: Calculus, Mouth Breathing, Oral Hygiene

\section{öz}

Kötü oral hijyen, olumsuz lokal ve sistemik faktörlerle birleșince daha şiddetli periodontal hastalıklar görülebilir.

17 yaşında, kız hasta, kliniğimize diş ve dişeti problemleri ile başvurdu. İntraoral muayenede oral hijyenin yetersiz olduğu ve okluzal yüzeye kadar uzanan şiddetli diştaşı varlığı (yaklaşık $20 \mathrm{~mm} \times 12 \mathrm{~mm}$ ) görüldü. Tıbbi anamnezinde dikkate değer bir bulguya rastlanılmadı ancak ağız solunumu yaptığı ve çevresi ile iletişim kurmakta zorlandı öğrenildi. Periodontal tedavi olarak oral hijyen eğitimi verildi ve düzenli aralıklarla debridman yapıldı. Takip eden kontrol seanslarında hastanın tedaviden memnun olduğu, oral hijyenine dikkat ettiği ve özgüveninin arttığı gözlendi. Tatmin edici iyileşmeden sonra sorunların tekrarlanmasını önlemek için hasta Ortodonti ve Kulak Burun Boğaz kliniklerine sevk edildi.

İyi ağız hijyeni eğitimi ve başlangıç periodontal tedavi ile ciddi periodontal problemler çözülebilir ve yaşam kalitesi iyileştirilebilir. Anahtar Kelimeler: Diştaşı, Ağız Solunumu, Oral Hijyen

\footnotetext{
* Ataturk University Faculty of Dentistry Department of Periodontology, Erzurum.

${ }^{\text {F}}$ A summary of this case report is shown in TDB 24th International Dental Congress Sept'27-30'2018, Ankara/ TURKEY as a poster presentation $(\boldsymbol{P}-156)$

Kaynakça Bilgisi: Öztaş GA, Orbak R. Şiddetli diştaşı varlığı ve cerrahisiz periodontal tedavi: bir olgu sunumu. Atatürk Üniv Diş Hek Fak Derg 2020; 30: 645-9. Citation Information: Oztas GA, Orbak R. Severe dental calculus and non-surgical periodontal treatment: a case report. J Dent Fac Atatürk Uni 2020; 30: 645-9.
}

\section{BACKGROUND}

Periodontal diseases are the most common oral diseases in the world and the most common types are gingivitis and chronic periodontitis. Different periodontal diseases can be observed in children and adolescents. Among these diseases, plaque-related gingivitis is the most frequent disease with more than $90 \%$ prevalence. Epidemiological data indicate that plaque-induced gingivitis is prevalent in all age groups and increases from the time of deciduous teeth growth in children to the highest point in puberty ${ }^{1}$.

Microbial dental plaque is considered to be the primary etiological factor for periodontal diseases. In cases where oral hygiene is not sufficient, microbial dental plaque starts to accumulate on the tooth surface. The toxic products of microorganisms in the 
plaque and various inflammatory mediators secreted by the host against these toxins cause periodontal diseases. The microorganisms in the plaque structure lead to nonspecific tissue destruction by toxic and enzyme secretion. The host defense system is activated and tissue inflammation occurs with various inflammatory mediators secreted by the host ${ }^{2}$. The relationship between microorganisms and host response is the most important factor that determines the onset, progression, and severity of periodontal disease ${ }^{3}$. In the continuation of inflammatory reactions gingivitis occurs. At the advanced inflammatory process, periodontitis with alveolar bone and periodontal ligament destruction is observed ${ }^{2}$.

If salivary and dental crevicular fluid based amorphous structure and microorganism organic plaque matrix is not removed from the teeth, calcium phosphate crystals precipitate on the plaque and mineralization starts in ectopic calcification structure. Calcium phosphate is saturated by increasing the alkaline value of the mouth and saturation continues to increase. The $\mathrm{pH}$ of the mouth increases with the activities of microorganisms. This calcified structure is called calculus. The amount and localization of calculus variety between individuals depending on host response, oral hygiene habits, dietary habits, age, systemic diseases, frequency of professional care and local factors (such as enamel defects, gingival recessions). The calculus facilitates plaque formation. In the case of gingivitis, the calculus, which begins to accumulate as supragingival, spreads into subgingival tissues and progresses to periodontitis ${ }^{4}$.

The plaque-induced gingivitis starts from the gingival margin and spreads. With gingival inflammation, changes in gingival contour, color, and consistency are observed ${ }^{5}$. General clinical findings are erythema, edema, bleeding, and gingival enlargement. Proliferation in collagen epithelium, collagen fiber network destruction and increased inflammatory and immune cellular mediators are observed. Clinical and radiographic examination shows a stable periodontium without loss of attachment level and bone support ${ }^{6}$.

The aim of periodontal treatment is to remove the etiological factors of periodontal diseases such as microbial dental plaques and products. Patient motivation and oral hygiene education are very important in initial periodontal treatment. Mechanical plaque control is achieved by cleaning the crown and root surfaces of the teeth by scaling and subgingival root planing ${ }^{7}$. By eliminating the factor, the inflammatory condition is improved, the oral flora is transformed into a healthy state, and the demolition of periodontal tissues is reconstructed ${ }^{8}$.

In this case report, as well as the negative effects of large amounts of calculus on the oral tissues as a result of insufficient oral hygiene in the individual with enamel defects, the psychological effects of the individual on this condition were evaluated and appropriate periodontal treatment approach was discussed.

\section{CASE REPORT}

A 17-year-old girl with tooth and gum problems applied to our clinic upon her family's insistence. Clinical examination showed that oral hygiene was very inadequate. Presence of severe calculus overlying occlusal surface was observed in the teeth except for the occlusal function due to anterior open-bite (Fig. 1). The presence of severe halitosis, inflammation of the gums and pseudo pocket was also determined. In the radiological examination, the crown-root formation of the teeth, alveolar bone trabeculation, and levels were evaluated as normal (Fig. 2). In addition, it was noticed that the patient had long-term unilateral (right) mastication function and her daily water consumption was very inadequate $(<1-2$ cups per day). It was also obtained that the patient had difficulty in communicating with his environment and had a closed psychological structure. Before the treatment, the patient consent form was read and signed.

The patient was treated with minimal trauma using an ultrasonic device as an initial periodontal treatment. The size of the removed calculus was approximately $20 \mathrm{~mm} \times 12 \mathrm{~mm}$ (Fig. 3). After removal of the calculus, the teeth were found to have enamel defects. The patient was motivated and oral hygiene training was given. The patient has been informed about the use of both sides of her jaw evenly and equally during the meal and increase the daily water consumption. She was consulted with the Faculty of Medicine for advanced systemic examination. According to the results of the consultation, the values of the blood tests of the patient were found to be normal. At the control session, it was observed that the patient was satisfied with the periodontal treatment, she paid attention to her oral hygiene and her self-confidence increased.

For the continuation of the treatment, the patient was treated supragingival and subgingival debridement by using hand tools under local anesthesia. The patient was prescribed $3 \mathrm{mg} / \mathrm{ml}$ 
benzydamine hydrochloride $+2 \mathrm{mg} / \mathrm{ml}$ chlorhexidine digluconate (Chlorhexidine Fort Gargara ${ }^{\circledR} 200 \mathrm{ml} / 2$ times a day) for two weeks of use. In the follow-up of treatment, it was observed that gingival infection was recovered and pseudo-pockets decreased without requiring surgical intervention.

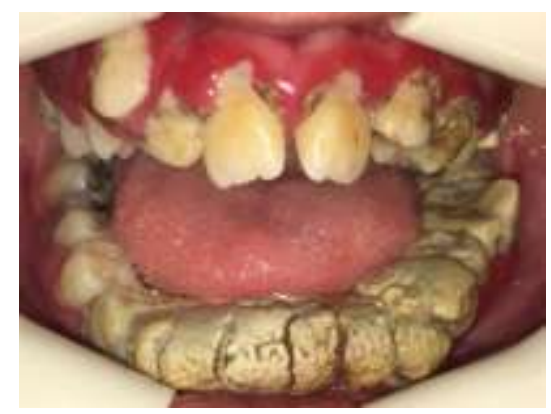

Fig. 1. The first attention in oral examination is the presence of severe calculus, anterior open bite, and the periodontal involvement of the lower jaw left side of the patient is more affected. Anterior group teeth cannot be seen because of the presence of severe calculus covering the occlusal surface

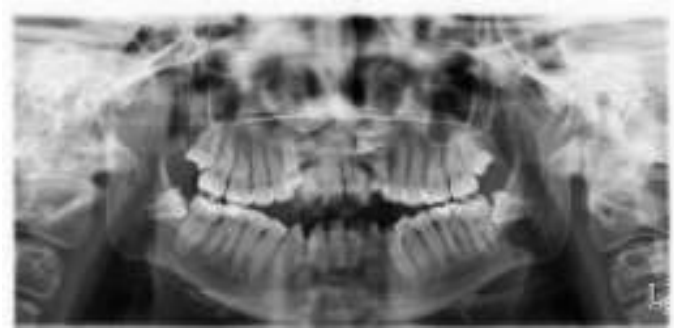

Fig. 2. In the radiological examination, the crown-root formation of the teeth, alveolar bone trabeculation, and levels were evaluated as normal

At the same time, the patient was evaluated for salivary glands in our Department of Oral Diagnosis and Radiology and no pathological condition was observed. At rest, $5 \mathrm{ml}$ of not stimulated saliva sample was taken from the patient and analyzed at the Department of Biochemistry at Ataturk University. The saliva $\mathrm{pH}$ value was determined as 7 .

The patient was followed in the first, third and sixth months (Fig. 4). When the patient came to her last session, it was seen that the cooperation is better and she is happy. She was consulted with the Otorhinolaryngology Clinic for not taking breathe nasal air and orthodontic clinic for tooth position anomalies.

The patient was informed about the case report. And the consent form was taken. Our study complies with ethical rules.

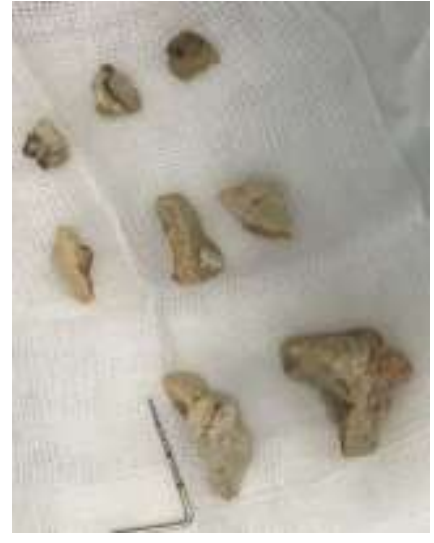

Fig. 3. The size of the removed calculus was approximately $20 \mathrm{~mm} \times 12 \mathrm{~mm}$

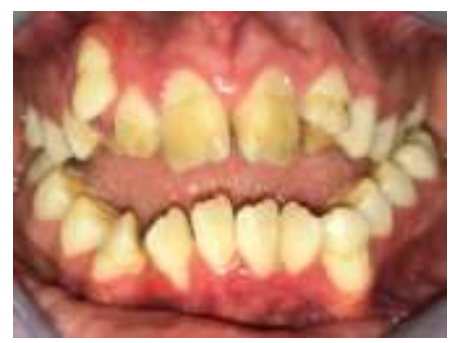

Fig. 4. Enamel defects became more prominent after cleaning the dental calculus.

In the follow-up, it was observed that gingival infection was recovered and pseudo-pockets decreased without requiring surgical intervention

\section{DISCUSSION}

The epidemiological studies on oral and dental health in our country show that individuals do not give importance to tooth and gum health and therefore tooth decay, gum problems and tooth loss are high ${ }^{9}$. It is well-known that poor oral hygiene, dental caries, and tooth loss lead to physiological, psychological and aesthetic problems in individuals. Our case was introverted, she did not want to communicate, her oral hygiene habits were weak and she was annoyed by her periodontal problems.

Curilovic et al. ${ }^{10}$ reported that the prevalence of gingivitis was over $90 \%$ in 8-17-years aged groups. In Malatya, Turkey, Eltas et al. $(2012)^{11}$ indicated the rate of gingivitis increased with increasing age and the prevalence of gingivitis was $90 \%$ in males at 14 years of age and 13 years old in females. In addition, Sutcliffe ${ }^{12}$ reported that hormonal changes in puberty were effective in oral care and gingivitis. In our case, the 17-year-old female patient had inadequate oral hygiene habits and she had severe calculus and inflammation. 
There are local and systemic factors that alter the gingival diseases with the presence of dental plaque. As the local factors include dental anatomic factors, dental restorations, root fractures ${ }^{13}$, the systemic factors include the endocrine system, drug use, hematological diseases, mouth breathing or malnutrition ${ }^{14}$. The anatomical factors of the teeth, tooth position disturbances (such as eccentricity, malocclusion, migration, occlusal forces) and tooth structure anomalies (such as enamel defects, enamel pearls, and protrusions, cavities, furcation zones) may affect plaque formation. Gingivitis, gingival growth, and pseudo pocket may be seen in the gums that are dehydrated because the lips do not cover the gingiva enough due to mouth breathing. In this case, the gingival tissue becomes more red, edematous, and bright $t^{15}$. In addition, the presence of defects due to the structure of the tooth also facilitates plaque formation. Mine hypoplasia occurs as a result of the development of the enamel organic matrix. Narrow horizontal bands, pits, and streaks, yellow to brown in the tooth are seen as colorations. This situation affects the firm structure and aesthetics of the tooth ${ }^{16}$. In the process of dental development, feverish disease, trauma, hypoxia, various systemic diseases, and systemic drugs may cause this condition. Structurally weaker teeth may become more prone to plaque formation ${ }^{17}$. The mechanical cleaning effect of foods during eating is very important in removing the plaque on the tooth surface. Individuals who have one-sided chewing due to habit or tooth and gingival problems are more likely to have plaque build-up on the side that is outside the function. If you do not pay attention to the individual plaque control, it causes the formation of unilateral calculus ${ }^{18}$. In our case, in addition to mouth breathing, there were enamel defects and unilateral chewing habit. In our case, in addition to mouth breathing, there were enamel defects. Such cases should be kept under control after finishing their treatment due to their tendency to tooth and gum problems. As a matter of fact, a periodic control session was conducted in our case.

Saliva secretion amount and $\mathrm{pH}$ values are important in oral health. In a healthy condition, salivary glands secrete an average of 1000-1500 ml of saliva, at least $500 \mathrm{ml}$ in a day. Saliva secretion may vary depending on the physiological status of the individual and the structural features of the salivary gland. Calcification and fibrous tissue formation in the salivary glands may cause to decline in secretion. The $\mathrm{pH}$ of the saliva is $6.7-7.4^{19}$. Low daily water consumption (at least 1.5-2litre / day) may result in a decrease in saliva secretion. It was learned that the daily water consumption was very low and the patient had dryness in his mouth. The patient was informed about the importance of consuming the appropriate amount of water. The patient was also evaluated in this subject since the acid-base balance may also affect the formation of dense calculus. Biochemical analyses were performed in this context. The saliva $\mathrm{pH}$ value was measured as neutral $(\mathrm{pH} \mathrm{7)}$ and evaluated as between normal limits.

It was aimed to remove the sub and supragingival calculus (severe calculus) that we considered as the main factor of the current periodontal problems in our patient. Scaling is the basic procedure to remove the calculus from the tooth surface. This is followed by root planning the process of scraping and cleaning the surface of the cement that has been contaminated with bacteria and products. Patients with gingivitis and mild periodontitis (loss of $1-2 \mathrm{~mm}$ attachment) may be treated with one or more sessions of initial periodontal treatment and motivation for oral hygiene. In advanced periodontitis diseases, initial periodontal therapy is accompanied by surgical periodontal treatments.

Hand tools and ultrasonic devices can be used for Scaling and Root Planning (SRP) ${ }^{20}$. In our case, the first session debridement procedures were performed using ultrasonic devices to provide patient comfort. In the following sessions, hand tools and ultrasonic devices were used together.

If the cases of plaque-induced gingivitis are not treated, there is a retreat towards the apical in the gingiva with host responded. Parallel to the loss of the gum, the tooth begins to lose its hard tissue support. With the loss of attachment and destruction of dental support tissues, the case progresses to periodontitis. And it comes to a point of no return.

Dental and gum problems may lead to negative effects on health and quality of life if not treated. Good oral hygiene provides the person with healthy teeth and gums, as well as self-confidence and high quality of life.

None of the authors of this article has any relationship, connection or financial interest with respect to the subject or material mentioned in the article. 


\section{REFERENCES}

1. Oh T J, Eber R, Wang, H L. Periodontal diseases in the child and adolescent. J Clin Periodontol 2002; 29: 400-10.

2. Miyasaki K, Nisengard R, Haake S. Immunity and inflammation; basic concepts. Carranza's Clinical Periodontology Co Philadelphia WB Saunders8th Ed 2002: 122-3.

3. Page R C, Offenbacher S, Schroeder H E, Seymour G J, Kornman K S. Advances in the pathogenesis of periodontitis: summary of developments, clinical implications and future directions. J Periodontol 2000; 14: 216-48.

4. White D J. Dental calculus: recent insights into occurrence, formation, prevention, removal and oral health effects of supragingival and subgingival deposits. Eur J Oral Sci 1997; 105: 508-22.

5. Lang N, Nyman S, Senn C, Joss A. Bleeding on probing as it relates to probing pressure and gingival health. J Clin Periodontol 1991; 18: 25761.

6. Page R C, Kornman K S. The pathogenesis of human periodontitis: an introduction. J Periodontol 2000; 14: 9-11.

7. Cobb C M. Non-surgical pocket therapy: Mechanical. Ann Periodontol 1996; 1: 443-90.

8. Caffesse R G, Mota L F, Morrison E C. The rationale for periodontal therapy. J Periodontol 2000; 9: 7-13.

9. Saydam G, Oktay I. Periodontal health status and treatment needs for index age groups in Turkey based on CPITN values. J Nihon Univ Sch Dent 1991; 33: 147-51.

10. Curilović Z, Mazor Z, Berchtold H. Gingivitis in Zurich schoolchildren. A reexamination after 20 years. Schweizerische Monatsschrift Fur Zahnheilkunde $=$ Revue Mensuelle Suisse D'odontoStomatologie 1977; 87: 801-8.

11. Eltas A, Guler C, Uslu M Ö, Dündar S. Ersöz M, Eltas Ş D. Malatya şehir merkezi ve yakın beldelerde 7-14 yaş arasındaki çocuklarda periodontal durumun değerlendirilmesi. Atatürk Üniv Diş Hek Fak Derg 2012; 2: 108-13.

12. Sutcliffe P. A longitudinal study of gingivitis and puberty. J Periodont Res 1972; 7: 52-8.

13. Blieden T M. Tooth-related issues. Ann Periodontol 1996; 4: 91-6.

14. Mariotti A. Dental plaque-induced gingival diseases. Ann Periodontol 1996; 4: 7-17.
15. Lite T, DiMaio D J, Burman L R. Gingival pathosis in mouth breathers: a clinical and histopathologic study and a method of treatment. Oral Surg Oral Med Oral Pathol Oral Radiol Endod 1998; 8: 38291.

16. Martos J, Gewehr A, Paim E. Aesthetic approach for anterior teeth with enamel hypoplasia. Contemp Clin Dent 2012; 3: 82.

17. Rodd H, Abdul-Karim A, Yesudian G, O'Mahony J, Marshman Z. Seeking children's perspectives in the management of visible enamel defects. Int J Paediatr Dent 2011; 21: 89-95.

18. Larato D. Effects of unilateral mastication on tooth and periodontal structures. J Oral Med 1970; 25: 80-3.

19. Guggenheimer J, Moore P A. Xerostomia: etiology, recognition and treatment. JADA 2003; 134: 61-9.

20. Berberoğlu $A$, Çaygür $A$, Baba $M A$, Tümer $H$, Yılmaz G. Diştaşlari temizliği, kök yüzeyi düzleştirmesi ve polisajda güncel kavramlar: derleme. Atatürk Üniv Diş Hek Fak Derg 2014; 24: 3.

\section{Sorumlu Yazarın Yazışma Adresi}

Arş. Gör. Dt. G. Alev ÖZTAŞ

Ataturk University

Faculty of Dentistry

Department of Periodontology, Erzurum

mobile: +90506 3279811

email: alev.oztas@atauni.edu.tr 